\title{
Biodiversity of Bear Seamount, New England Seamount Chain: Results of Exploratory Trawling
}

\author{
J. A. Moore \\ Florida Atlantic University, Honors College, Jupiter, FL 33458, USA \\ M. Vecchione, B. B. Collette and R. Gibbons \\ National Marine Fisheries Service, National Systematics Laboratory, \\ National Museum of Natural History, Smithsonian Institution, Washington, DC 20560 \\ K. E. Hartel \\ Museum of Comparative Zoology, Harvard University, Cambridge, MA 02138, USA \\ J. K. Galbraith \\ National Marine Fisheries Service, Northeast Fisheries Science Center, Woods Hole, MA 02453, USA \\ M. Turnipseed, M. Southworth, and E. Watkins \\ Virginia Institute of Marine Sciences, Gloucester Point, VA 23062, USA
}

\begin{abstract}
Bear Seamount $\left(39^{\circ} 55^{\prime} \mathrm{N} 67^{\circ} 30^{\prime} \mathrm{W}\right)$ is an extinct undersea volcano located inside the U.S. Exclusive Economic Zone south of Georges Bank. The fauna associated with the seamount was little known until twenty trawl stations were made 2-7 December 2000, by the NOAA ship R/V Delaware II. The objective of the survey was to begin to document the biodiversity on and over the seamount, particularly of fishes, cephalopods, and crustaceans. Representatives of most species were preserved as vouchers and for subsequent definitive identification. This report presents a description of the biodiversity. A total of at least 274 species were collected. Preliminary identifications indicate the capture of 115 fish species. Among these were a number of new fish records for the area or rare species, including Acromycter pertubator (Congridae), Diastobranchus capensis (Synaphobranchidae), Alepocephalus bairdii (Alepocephalidae), Mirognathus normani (Alepocephalidae), Bathygadus favosus (Bathygadidae), Nezumia longebarbata (Macrouridae), Gaidropsarus argentatus (Phycidae), Dibranchus tremendus (Ogcocephalidae) and Kali indica (Chiasmodontidae). Only two fish species of potential commercial importance were encountered: Coryphaenoides rupestris and Macrourus berglax. Cephalopods comprised 26 species from 15 families, including one new distributional record and several rarely-collected species. The crustacean fauna was diverse with at least 46 species. Totals for other invertebrate species are pending laboratory identification, but number at least 87 species from 10 Phyla. This includes a number of new distributional records and a new species of gorgonian.
\end{abstract}

Key words: biodiversity, deep-sea, fauna, fishes, invertebrates, North Atlantic, seamount

\section{Introduction}

Seamounts represent biological islands in the deep sea and often feature characteristic faunas that are quite different from those found in the surrounding soft sediment and abyssal habitats. Large depth ranges, hard substrates, steep gradients, complex topography, impinging currents, topographically induced upwellings, clear oceanic water, and geographic isolation all combine to make seamounts specialized habitats for deep-sea organisms (Rogers, 1994). The benthic fauna on seamounts include species that cre- ate structural habitat diversity and likely create essential habitats for some deep-sea fishes and crustaceans.

The New England Seamounts (NES) make up the longest seamount chain in the North Atlantic, encompassing more than 30 major volcanic peaks extending southeast from Georges Bank for about $1200 \mathrm{~km}$ to the eastern end of the Bermuda Rise, ending abruptly with Nashville Seamount to the East North East of Bermuda (Fig. 1). The major peaks of the NES rise as much as $4000 \mathrm{~m}$ above the Sohm Abyssal Plain. 


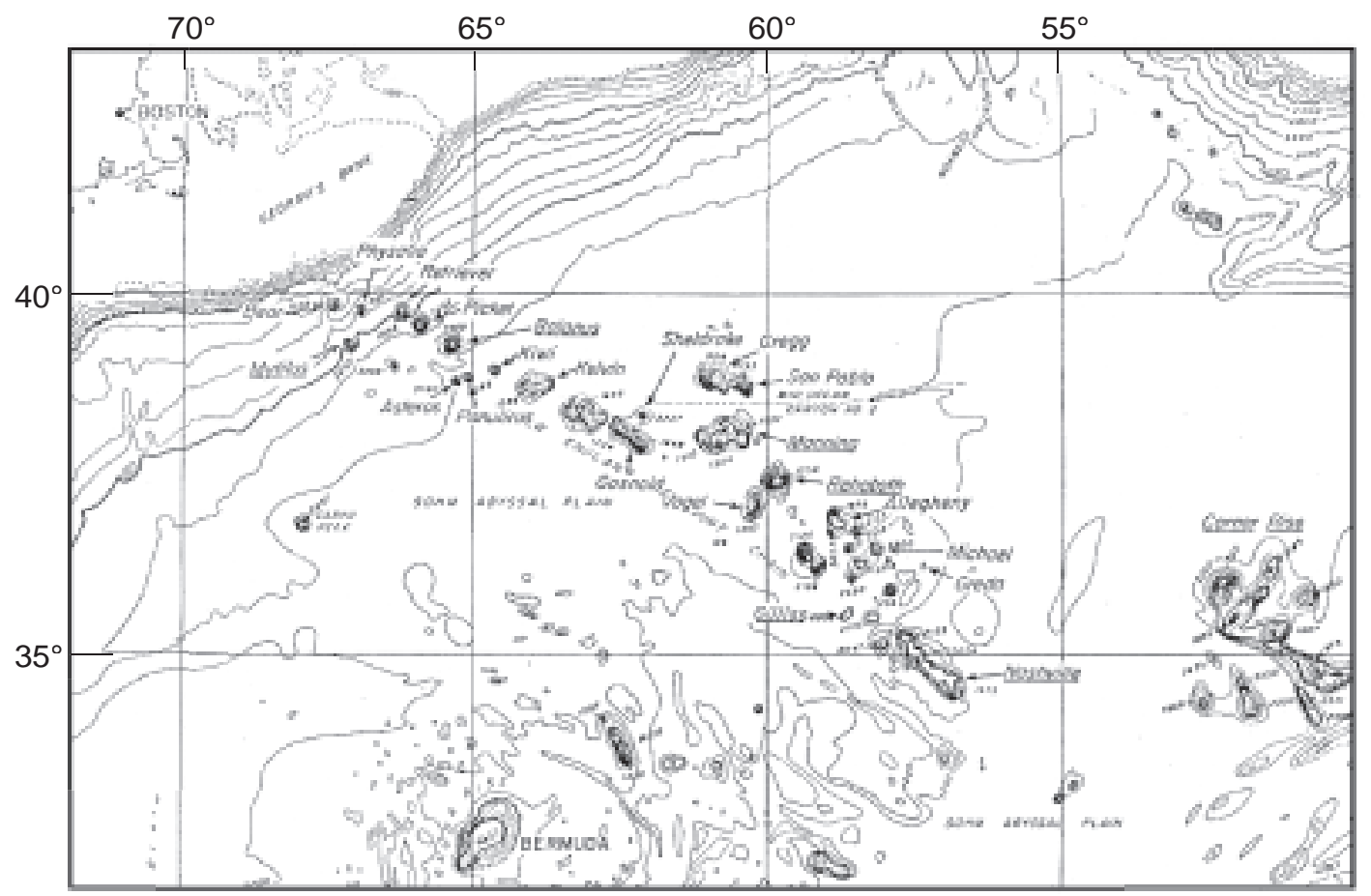

Fig. 1. Bathymetric chart of the New England Seamount chain showing depth contours (m) (from Houghton et al., 1977).

About $300 \mathrm{~km}$ east of Nashville Seamount, the Corner Rise Seamounts form a cluster of peaks midway between the eastern end of the NES and the Mid Atlantic Ridge. The NES and Corner Rise Seamounts resulted from a mantle-plume hotspot, which moved towards the Mid Atlantic Ridge and currently resides underneath Great Meteor Seamount (Sleep, 1990).

The NES chain lies roughly perpendicular to two major currents, the Gulf Stream, flowing to the northeast, and the Deep Western Boundary Current, which flows southwesterly along the continental slope (Hamilton et al., 1996). In addition, the Antarctic Bottom Water flows around the bases of the seamounts at the eastern end of the chain. These seamounts alter the flow of the currents in their vicinity (Vastano and Warren, 1976; Hogg et al., 1986), which may influence the recruitment of benthic and pelagic organisms.

While the geology of the NES and the effects of the seamounts on the Gulf Stream have been extensively studied, the biota has been almost completely ignored (Zeigler, MS 1955; Uchupi et al., 1970; Vastano and Warren, 1976; Houghton et al., 1977; Heirtzler et al., MS 1977 and 1977; Hogg et al., 1986).
A review of the biogeography of seamount fauna around the world (Wilson and Kaufman, 1987) makes note of only one species known from the entire NES chain (the stony coral Enallopsammia rostrata from Gregg Seamount). Because of this dearth of biotic information, the NES was excluded from a recent discussion on the biology of seamounts around the world (Rogers, 1994).

Examinations by one of us (JAM) of archived photos taken during the geological investigation of the NES has found that more than 50 species of invertebrates and at least eight species of fishes do in fact live on these seamounts. Exploratory commercial fishing in 1997 on Bear Seamount (the closest NES to the U.S.) captured another seven fish species, including two species previously known from the eastern Atlantic (Hydrolagus pallidus and Bathypterois dubius) and one previously found only in the temperate southern hemisphere (Diastobranchus capensis; Moore et al., 2003). Clearly, much can be done to investigate the NES fauna and integrate that information into the extensive knowledge gained from other seamounts in the Atlantic, Pacific, and elsewhere in the world. 
With the increase of deep-sea fisheries, interest in commercially fishing seamounts has increased (Koslow, 1997). Yet seamounts hold concentrations of sessile suspension-feeding invertebrates, such as scleractinians, gorgonians and sponges, that add structural complexity, and there are concerns about the impact of fishing activities on these invertebrates (Dayton et al., 1995; Auster et al., 1996; Probert et al., 1997; Koslow and Gowlett-Holmes, MS 1998; Moore and Mace, 1999; Koslow et al., 2000). A recent haul of Darwin's roughy (Gephyroberyx darwini, also known as big roughy) from a canyon on the south side of Georges Bank generated renewed interest by some U.S. fishers in exploring the deepwater fishery resources of New England. One fishing company put forward a specific proposal to explore the fishery resources on Bear Seamount. This coincided with planning by the National Marine Fisheries Service (NMFS) to conduct an exploratory survey to Bear Seamount in late-2000. One objective of this survey was to begin to document the biodiversity on and over the seamount, particularly of fishes, cephalopods, and crustaceans before large-scale commercial fishing begins. Knowledge of the fauna associated with the seamounts is considered crucial in assessing the impacts of any subsequent commercial fishing on these seamounts and a lack of this kind of information has hindered assessments of fishing impacts in other areas (Koslow and Gowlett-Holmes, MS 1998).

Bear Seamount $\left(39^{\circ} 55^{\prime} \mathrm{N} 67^{\circ} 30^{\prime} \mathrm{W}\right)$ is an extinct undersea volcano located inside the U.S. Exclusive Economic Zone south of Lydonia Canyon on Georges Bank. Bear Seamount rises from the continental slope at depths of 2000-3 $000 \mathrm{~m}$ to a generally flat summit at a depth of $1100 \mathrm{~m}$ below the sea surface. Although the upper surface of Bear Seamount is draped in many places with thick sediment, there are also outcrops of basaltic volcanic rock and scattered glacial erratics varying in size from small pebbles to large boulders. These glacial erratics most likely fell to the seamount after dropping from icebergs calving off the glaciers that extended to Georges Bank during the Pleistocene.

Bear Seamount was first identified, named and sonar mapped during a series of surveys by Woods Hole Oceanographic Institution (WHOI) vessels in 1954 (Zeigler, MS 1955). Subsequent investigations of Bear Seamount include more sonar mapping, one chain-bag dredge haul and one camera lowering in 1962 (R/V Atlantis cruise A-281; Pratt and Thompson,
MS 1962), two Alvin dives in 1968 (Alvin dive 286 and 287), and a commercial exploratory trawl by the F/V Matthew Melissa out of Stonington, Connecticut, in 1997. A list of taxa identified from these previous studies is given in Table 1.

Prior to our first cruise in 2000 , several invertebrates and a few fishes were identified from archived photos from Atlantis cruise A-281 and Alvin dives 286 and 287. The archived photos are available at the Document Library of Woods Hole Oceanographic Institution. In addition, several fish specimens were acquired from a commercial trawler that conducted a few deepwater exploratory tows on the top of Bear Seamount in 1997. These specimens are deposited at the Ichthyology Collection of the Peabody Museum of Natural History, Yale University.

\section{Materials and Methods}

Twenty hauls were made on or over Bear Seamount using double-warp gear towed from the NOAA vessel R/V Delaware II from 2-7 December 2000 (cruise DE00-11). Of these hauls, 11 were fully pelagic tows and 9 actually touched bottom, if only briefly in some instances. Each tow was for one hour once the net was set at the selected depth, however, bottom tows were not necessarily in contact with the bottom that entire time. Tow depths were between 900-2 $500 \mathrm{~m}$. Six hauls were made with an IYGPT midwater trawl, five hauls with a NMFS standard shrimp trawl, and nine tows with a Yankee 36 otter trawl. The differing biases and catchabilities of these three kinds of nets, plus the unknown amount of time spent trawling the bottom, make explicit calculations of diversity indices suspect. Catches were sorted and given preliminary identifications on shipboard. Tissue samples of many fish and cephalopod taxa were taken for DNA analysis (samples of fishes are deposited at the Museum of Natural History, University of Kansas). Representatives of most species were preserved as vouchers. The voucher specimens are deposited in the Museum of Comparative Zoology at Harvard University (most of the fish specimens), Peabody Museum of Natural History at Yale University (some invertebrates), and the National Museum of Natural History, Smithsonian Institution (some fishes and most of the invertebrates). Many specimens were sent to taxonomic experts for subsequent definitive identification. A list of those experts is given in the acknowledgments. 
TABLE 1. Taxa seen or sampled from Bear Seamount prior to 2000.

PROTISTA

Globose syringaminid? xenophyophore

\section{PORIFERA}

Unidentified sponges ( $>5 \mathrm{spp}$.)

\section{CNIDARIA}

Cerianthid anemone

Unidentified large light-colored anemone

Desmophyllum cristagalli scleractinian coral

Lepidisis sp.unbranched spiral whip coral

Primnoa sp. gorgonian coral

Pinnate antipatherian corals

Anthophilum sp. sea pen

\section{SIPUNCULIDA}

Unidentified sipunculid worm

\section{ANNELIDA}

Hyalinoecia sp. polychaete worm

\section{ARTHROPODA}

Neolithodes sp. stone crab

Unidentified spider crab assoc. w/ urchin

\section{ECHINODERMATA}

Solaster sp. sunstar

Porania sp. sea star

\section{Results}

Table 2 provides a list of the species collected during cruise DE00-11 and identified to date. We report a total of at least 274 species collected on or over Bear Seamount (Table 1 contains an additional 12 species not in Table 2 to give a total of at least 286 species known from Bear Seamount). The numbers of individuals for each species were recorded to give a qualitative sense of the relative abundances. For some very abundant animals (e.g. euphausids, Cyclothone, Sergestes and Pasiphaea), only a small number of representative specimens were counted and kept, while for some fragmentary animals (e.g. hexactinellid sponges, Lophelia pertusa and Lepidisis) not all individuals were determinable. In addition, some ani-
Neomorphaster sp. small 5-arm sea star Ophiomusium lymani brittle star Unidentified light brittle stars Echinus affinis urchin

Echinothuriid pancake urchin

Unidentified 5-arm bathycrinid crinoid

Peniagone sp. sea cucumber

\section{UROCHORDATA}

Large transparent unstalked tunicate

PISCES

Hydrolagus pallidus chimaera* Apristurus sp. deepwater catshark* Bathyraja sp. skate

Unidentified notacanthid spiny eel Unidentified halosaur

Serrivomer beanii sawpalate eel*

Diastobranchus capensis cuthroat eel*

Unidentified cutthroat eel

Unidentified alepocephalid smoothhead

Bathypterois dubius spiderfish*

Coryphaenoides sp. grenadier

Unidentified morid codling

Anoplogaster cornuta fangtooth*

Antigonia capros deepbody boarfish*

Sebastes sp. redfish

Zoarces atlanticus eel-pout

* identified by J. A. Moore, from commercial trawl 1997.

mals were badly damaged by the trawl nets and difficult to identify (e.g. Myctophidae indet. and Cyclothone sp. indet.).

Preliminary identifications indicate that 115 fish species were captured (Table 2). Several new fish records for the area or rare species were collected (Moore et al., 2003, including Acromycter pertubator (Congridae), Diastobranchus capensis (Synaphobranchidae), Alepocephalus bairdii (Alepocephalidae), Mirognathus normani (Alepocephalidae), Bathygadus favosus (Bathygadidae), Nezumia longe-barbata (Macrouridae), Gaidropsarus argentatus (Phycidae), Dibranchus tremendus (Ogcocephalidae), and Kali indica (Chiasmodontidae). The cephalopods comprised 26 species from 15 families, including one new 
TABLE 2. Taxa collected on or over Bear Seamount during NMFS cruise DE00-11 from 2-7 Dec 2000.

\begin{tabular}{lr}
\hline PROTISTA & \\
\hline Agglutinated foraminiferans (3+ spp. $)^{1}$ & $>20^{2}$ \\
\hline PORIFERA & \\
\hline Boring sponge (in gorgonian base) & 1 \\
Demospongae fragments & $>6$ \\
Small stoloniferous sponge & $>4$ \\
Geodia sp. & 1 \\
Hexactinellid fragments & $>6$
\end{tabular}

\section{CNIDARIA}

Scyphozoans (8+ spp.)

Poralia rufescens

Siphonophore pieces

Marrus orthocanna

Knobby pink anemone

Small white anemone

Amphianthus or Stephanauge sp.

Thecate hydroid attached to Lophelia

Epizoanthus paguriphilus

Caryophyllia ambrosia

Flabellum alabastrum

Vaughanella margaretata

Lophelia pertusa

Acanthogorgia angustiflora

Paragorgia sp.

Swiftia? sp.

Lepidisis sp.

Anthoptilum grandiflorum

Funiculina sp.

Anthomastis agassizii

\section{CHAETOGNATHA}

Chaetognaths

$>3$

\section{NEMERTEANS}

Nectonemertes mirabilis

Dinonemertes $\mathrm{cf}$. investigatoris

\section{ANNELIDA}

Polychaete burrowing in wood

Polychaete in tubes within Lophelia

\section{ANNELIDA (Continued)}

Serpulid with large triangular tubes

Serpulid with small round tubes

$>4$

$>40$

\section{MOLLUSCA}

Nudibranch

Calliotropis bairdii

Pleurotomella sp.

Gastropod sp. 1

Gastropod sp. 2

Gastropod sp. 3

Bivalve sp. 1

Heteropods

Pteropods

Clione sp.

\section{CEPHALOPODS}

Lampadioteuthis megaleia

Abralia veranyi

Abraliopsis hoylei

Pyroteuthis margaritifera

Pterygioteuthis gemmata

Pterygioteuthis giardi

Taningia danae

Octopoteuthis megaptera

Gonatus fabricii

Histioteuthis sp.

Histioteuthis dofleini

Histioteuthis reversa

Bathyteuthis abyssicola

Brachioteuthis sp.

Illex illecebrosus

Chiroteuthis sp.

Chiroteuthis spoeli

Chiroteuthis veranii

Mastigoteuthis sp.

Mastigoteuthis agassizi

Mastigoteuthis magna

Cranchiidae indet.

Taonius pavo

Teuthowenia megalops

Stauroteuthis syrtensis

Eledonella pygmaea

Macrotritopus defilippi

Graneledone verrucosa verrucosa

Vampyroteuthis infernalis

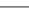

1

5

1

1

1

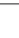
1

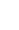
( ( .

\footnotetext{
${ }^{1}$ In a few instances, taxonomic experts indicated the number of species they could distinguish, without necessarily giving the explicit species names and these numbers of species are indicated below in parentheses following the taxonomic group name.

2 For some very abundant animals (euphausids, Cyclothone, and Pasiphaea), only a small number of representative specimens were counted and kept, and for some or fragmentary animals (e.g. Ophiomusium lymani and Lepidisis) not all individuals were determinable. These are noted with a $>$ sign before the actual number counted.
} 
TABLE 2. (Continued). Taxa collected on or over Bear Seamount during NMFS cruise DE00-11 from 2-7 Dec 2000.

\begin{tabular}{|c|c|}
\hline \multicolumn{2}{|l|}{ ARTHROPODA } \\
\hline Syscenus atlanticus & 27 \\
\hline Bopyrid isopod (in Glyphocrangon) & 1 \\
\hline Hyperiid amphipods indet. & $>49$ \\
\hline Hyperia galba & 2 \\
\hline Phronima sp. & 2 \\
\hline Unidentified large red amphipod 1 & \\
\hline Colossendeis colossea & 22 \\
\hline Scalpellum sp. 1 & \\
\hline Plesiopeneaus edwardsianus & 10 \\
\hline Acanthephyra sp. (4 spp.) & $>78$ \\
\hline Glyphocrangon sculpta & $>10$ \\
\hline Notostomus sp. & 4 \\
\hline Pasiphaea sp. (3 spp.) & $>51$ \\
\hline Gennadas sp. (3-4 spp.) & $>41$ \\
\hline Sergestes sp. (10 spp.) & $>130$ \\
\hline Homolids & 2 \\
\hline Oplophorus sp. & 1 \\
\hline Systellaspis sp. & 2 \\
\hline Euphausids & $>53$ \\
\hline Pandalus carinatus & 1 \\
\hline Stylopandalas sp. & 7 \\
\hline Polycheles granulatus & 12 \\
\hline Steromastis nana & 6 \\
\hline Polychelid spiny form & 2 \\
\hline Munidopsis sp. & 8 \\
\hline Galathaea rostrata & 1 \\
\hline Munidopsis curvirostra & 1 \\
\hline Mysids & $>69$ \\
\hline Gnathophausia zoea & $>24$ \\
\hline Parapagurus pilosimanus & 46 \\
\hline Neolithodes grimaldii & 1 \\
\hline Copepod parasite on Synbranchus eel & 1 \\
\hline
\end{tabular}

\section{ECHINODERMATA}

Crinoid fragments

Elasipodid holothurian

Psychropotes depressa

Plutonaster agassizi

Psilaster andromeda florae

Cheiraster sepitus

Persephonaster sp.

Ceramaster granularis

Mediaster bairdi

Pseudarchaster parelii

Neomorphaster forcipatus

Chondraster grandis

Henricia sp.

Pteraster sp.

Solaster benedicti

Zoroaster sp.

Brisingia costata

Freyella microspina

Freyella elegans

Asteroschema sp.

\section{ECHINODERMATA (Continued)}

Ophiomusim lymani >141

Ophiacanthidae sp.

Ophiacantha sp.

Amphiophiura saurura

Homophiura tessellata

Ophiocten gracilis

Ophiura ljungmani

Simple-armed basket star

Echinus affinis

Echinus sp.

Zygothuria lactea

Phorosoma placenta

Hygrosoma petersi

1

4

8
9

7

36

1

159

3

4

20

UROCHORDATA

Stalked tunicates

Thaliacean salps

Pyrosoma sp.

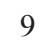

$>9$

$>3$

PISCES

Hydrolagus affinis

4

Apristurus manis

14

Apristurus profundorum 5

Etmopterus princeps $\quad 2$

Raja bigelowi 2

Aldrovandia sp. indet. $\quad 13$

Aldrovandia affinis $\quad 48$

Aldrovandia oleosa

Aldrovandia phalacra 171

Halosauropsis macrochir $\quad 4$

Notacanthus chemnitzi 4

Polyacanthonotus challengeri $\quad 1$

Polyacanthonotus rissoanus 3

Ilyophis brunneus 2

Diastobranchus capensis 1

Synaphobranchus sp. 17

Synaphobranchus kaupii 90

Derichthys serpentinus 1

Nessorhamphus ingolfianus 2

Nemichthys scolopaceus 10

Congridae larvae $\quad 7$

Acromycter perturbator 1

Ariosoma sp. Larvae $\quad 16$

Venefica procera 2

Serrivomer beanii $\quad 27$

Eurypharynx pelacanoides $\quad 11$

Bathylagus berycoides $\quad 1$

Bathylagus euryops $\quad 12$

Dolichopteryx sp. 2

Alepocephalus agassizi $\quad 8$

Alepocephalus australis $\quad 13$

Alepocephalus bairdii 1

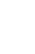


TABLE 2. (Continued). Taxa collected on or over Bear Seamount during NMFS cruise DE00-11 from 2-7 Dec 2000.

\begin{tabular}{|c|c|}
\hline \multicolumn{2}{|l|}{ PISCES (continued) } \\
\hline Alepocephalus cf. umbriceps & 1 \\
\hline Bajacalifornia megalops & 1 \\
\hline Mirognathus normani & 1 \\
\hline Narcetes stomias & 1 \\
\hline Rouleina attrita & 1 \\
\hline Maulisia sp. & 2 \\
\hline Cyclothone sp. indet. & 332 \\
\hline Cyclothone pallida & 1 \\
\hline Cyclothone microdon & $>308$ \\
\hline Gonostoma bathyphilum & 32 \\
\hline Gonostoma elongatum & 58 \\
\hline Chauliodus sloani & 34 \\
\hline Argyropelecus aculeatus & 16 \\
\hline Argyropelecus hemigymnus & 4 \\
\hline Sternoptyx diaphana & 18 \\
\hline Sternoptyx pseudobscura & 1 \\
\hline Valenciennellus tripunctulatus & 1 \\
\hline Vinciguerria nimbaria & 1 \\
\hline Malacosteus niger & 7 \\
\hline Aristostomias tittmani & 1 \\
\hline Bathophilus pawneei & 1 \\
\hline Borostomias antarcticus & 1 \\
\hline Leptostomias longibarba & 1 \\
\hline Melanostomias bartonbeani & 2 \\
\hline Photostomias guerneri & 4 \\
\hline Stomias boa ferox & 20 \\
\hline Stomias affinis & 1 \\
\hline Bathypterois phenax & 28 \\
\hline Bathypterois quadrifilis & 16 \\
\hline Scopelosaurus lepidus & 1 \\
\hline Bathysaurus ferox & 3 \\
\hline Arctozenus rissoi & 1 \\
\hline Paralepis sp. & 2 \\
\hline Paralepis coregonoides & 1 \\
\hline Myctophidae indet. & 97 \\
\hline Benthosema glaciale & 73 \\
\hline Ceratoscopelus maderensis & 18 \\
\hline Ceratoscopelus warmingii & 5 \\
\hline Diaphus brachycephalus & 1 \\
\hline Diaphus dumerili & 9 \\
\hline Diaphus rafinesquii & 4 \\
\hline Hygophum taaningi & 1 \\
\hline Lampadena speculigera & 1 \\
\hline Lampanyctus photonotus & 4 \\
\hline Lobianchia dofleini & 30 \\
\hline
\end{tabular}

distributional record (i.e. Chiroteuthis spoeli) and several rarely-collected species. The crustacean species numbered at least 46 species and again included unusual species. For example, a redescription of a rare isopod species (Syscenus atlanticus, previously known only from off Iceland) has been submitted for publi-
PISCES (continued)

Lobianchia gemellari 2

Myctophum affine 3

Nannobrachium atrum 1

Nannobrachium lineatum $\quad 7$

Nannobrachium medonaldi 3

Nannobrachium lineatum 7

Nannobrachium mcdonaldi 3

Notoscopelus resplendens 2

Symbolophorus veranyi 1

Dicrolene intronigra 2

Penopus microcephalus 1

Porogadus miles 4

Bassogigas gilli 1

Bathygadus favosus 5

Coryphaenoides alateralis $\quad 2$

Coryphaenoides carapinus $\quad 36$

Coryphaenoides rupestris $\quad 89$

Macrourus berglax $\quad 25$

Nezumia longebarbata 5

Nezumia sclerorhynchus 1

Nezumia suilla 2

Sphagemacrurus grenadae 4

Trachonurus sulcatus 2

Antimora rostrata 20

Gaidropsarus ensis 2

Gaidropsarus argenteus 1

Halargyreus johnsoni 15

Dibranchus tremendus $\quad 1$

Cryptopsaras couesii 2

Melamphaes microps 1

Melamphaes suborbitalis $\quad 4$

Poromitra megalops 3

Scopelogadus beanie $\quad 23$

Scopeloberyx opisthopterus 33

Anoplogaster cornuta 1

Cottunculus thomsoni 1

Howella brodei 1

Anthias nicholsi larva $\quad 1$

Platyberyx opalescens 1

Lycodes atlanticus 6

Melanostigma atlanticum 1

Chiasmodon niger 4

Kali indica 1

Glyptocephalus cynoglossus larvae $\quad 3$

Poecilopsetta beani larva 1

cation based in part on specimens from Bear Seamount (Kensley, 2003). Totals for other invertebrate species are pending laboratory identification, but number at least 87 species in 10 Phyla. Notable captures of other invertebrates include a solitary coral, Vaughanella margaretata, which represents the first record of this 
species since its original description over one hundred years ago (S. Cairns, National Museum of Natural History, Smithsonian Institution, Washington, D.C., USA, pers. comm.). We have also been informed of a number of new distributional records and an undescribed species of gorgonian (F. Bayer, National Museum of Natural History, Smithsonian Institution, Washington, D.C., USA, pers. comm.)

Only two fish species of potential commercial importance were encountered: Coryphaenoides rupestris and Macrourus berglax. Coryphaenoides rupestris, the roundnose grenadier, was caught at 4 stations at depths of 1 100-1800 m. They ranged from $47-103 \mathrm{~cm}$ total length, with an average length of 85 $\mathrm{cm}$ total length. A total of 89 individuals were caught, with the highest catch of 46 individuals at one station, weighing a total of $65.1 \mathrm{~kg}$. Macrourus berglax, the roughhead grenadier, was captured at 5 stations, also at depths of 1 100-1 $800 \mathrm{~m}$. They ranged from $31-104 \mathrm{~cm}$ total length, with an average length of 50 $\mathrm{cm}$. Twenty-five individuals were caught, with a highest single catch of 10 individuals.

The only commercially exploited cephalopod captured, Illex illecebrosus, consisted of just two individuals. Only a few exploited or potentially exploitable crustaceans were taken from Bear Seamount (a few isolated individuals of scarlet shrimp, Plesiopeneaus edwardsianus, several glass shrimps, Pasiphaea spp., and the porcupine stone crab, Neolithodes grimaldii; Pohle et al., 1992).

\section{Discussion}

Our results have some bearing on statements made by Wilson and Kaufman (1987) in their review of seamount biota. For instance, they state that although ophiuroid brittlestars are widespread and common in deep-sea sedimentary environments, they have been reported from very few seamounts. Our survey collected a number of ophiuroid species and found the brittlestar Ophiomusium lymani to be common in all the benthic trawls. Archived photos of other seamounts in the NES chain also show numerous brittlestars on soft sediment, on rocks, and perched in the fronds of gorgonians (see Fig 9 in Houghton et al., 1977).

Wilson and Kaufman (1987) also state that few of the reported seamount crustaceans are truly benthic. However, we collected a number of benthic crustacean species from Bear Seamount. A large spider crab, Neolithodes grimaldii, and numerous hermit crabs,
Parapagurus pilosimanus, were taken, as were a variety of polychelid and galatheid crustaceans. Also, a gooseneck barnacle (Scalpellum sp.) was collected attached to a small glacial pebble. Archived photos from the two Alvin dives on Bear Seamount show a Neolithodes in a shallow dish-like depression, an unidentified small spider crab associated with an urchin, and large red shrimp, possibly Plesiopenaeus edwarsianus, just inside the mouths of small burrows in the soft sediment.

With regards to seamount fish fauna, Wilson and Kaufman (1987) state that fishes are associated with seamounts elsewhere, but have not been reported from the western North Atlantic seamounts. This was true at the time of that paper. Since then, Vinnichenko (1997) published a list of the fishes found on the Corner Rise Seamounts (about $300 \mathrm{~km}$ east to the eastern end of the NES). That faunal list compares well with our list of fishes from Bear Seamount. The main difference is that the Corner Rise features many species more typically found in the deep waters of the eastern North Atlantic, while our list has many more western North Atlantic deepwater species. However, a few eastern Atlantic species (e.g. Hydrolagus pallida and Bathypterois dubius) were found on Bear Seamount and may indicate that the NES chain provides a westward route of dispersal for at least some eastern Atlantic species.

Large pieces of live Lophelia pertusa were collected from two of the bottom hauls indicating that deepwater coral banks may exist on this seamount. Evidence of Lophelia sp. has also been noted from other areas of NES (Pratt and Thomson, MS 1962; Heirtzler et al., MS 1977). This species has been associated with very diverse communities elsewhere in the North Atlantic (Jensen and Frederiksen, 1992; Mortensen et al., 1995; Rogers, 1999). Similarly diverse communities may also be present on Bear Seamount. We can note the following invertebrates found in direct association with the L. petusa trawled from Bear Seamount: a large polychaete worm living in tubular spaces within the coral colony, attached solitary coral, Caryophila ambrosia, small serpulid worm tubes, a thecate hydroid, and the octocoral Swiftia.

Even though Bear Seamount rises up out of the continental slope of Georges Bank, it apparently provides sufficiently unusual habitats or conditions that allow various species not generally reported from the nearby slope to live on the seamount. Three of us have 
worked on a checklist of deepwater fish species for all of New England (Moore et al., 2003). The trawls on Bear Seamount resulted in six new additions to that checklist. Our regional list of deep-sea fishes recorded about 591 species in the vicinity of Georges Bank, from the slope to the abyssal plain, whereas we report 115 fish species from Bear Seamount. It is clear that this investigation of Bear Seamount is quite preliminary and that many more species of fishes and invertebrates will likely be found associated with the seamount. Because of the more unusual habitats on the seamount, it is also quite possible that more new additions to the region will also be found on the seamount.

Similarly, the cephalopods from this survey add to the slope fauna recently compiled by Vecchione (2000) and Vecchione and Pohle (2002). Photographs of some of these unusual cephalopods have been added to the cephalopod section of the Tree of Life project on the World Wide Web at:

http://tolweb.org/tree/eukaryotes/ animals/mollusca/ cephalopoda/cephalopoda.html

The numerous novel records of species associated with the seamount in our study could indicate that there is some degree of separation of the seamount fauna from the nearby continental slope, or our ignorance of what lives in the deep sea may still be so great that a single survey can add much new information, despite many deepwater investigations in the region over the last 130 years.

\section{Acknowledgements}

We are grateful to the following taxonomic experts who helped identify specimens from the various groups indicated: Susan Richardson (Foraminifera and Xenophyophora), Florida Atlantic University, Larry Madin (Scyphozoa) Woods Hole Oceanographic Institution, Steve Cairns (Scleractinia), Ted Bayer (Octocorallia), Ed Petuch (Bivalvia and Gastropoda), Jon Norenburg (Nemertea), Brian Kensley (Arthropoda), Dave Pawson (Echinodermata) all from Simithsonian Institution, Eric Lazo-Wasem (various invertebrates) Peabody Museum, Yale University, and Tomio Iwamoto (Macrouridae) California Academy of Science. Our thanks go to the captain and crew of the R/V Delaware, who worked hard, despite adverse seas and equipment failures, to make this cruise so successful. Thanks also go to Capt. Walter Allyn of the F/V Matthew Melissa for providing specimens from the exploratory trawling in 1997.

\section{References}

AUSTER, P. J., R. J. MALTESTA, R. W. LANGTON, L. WATLING, P. C. VALENTINE, C. L. S. DONALDSON, E. W. LANGTON, A. N. SHEPARD, and I. G. BABB. 1996. The impacts of mobile fishing gear on seafloor habitats in the Gulf of Maine (Northwest Atlantic): Implications for conservation of fish populations. Rev. Fish. Sci., 4(2): 185-202.

DAYTON, P. K., S. F. THRUSH, M. T. AGARDY, and R. J. HOFMAN. 1995. Environmental effects of marine fishing. Aquat. Conserv.: Mar. Freshw. Ecosyst., 5: 205-232.

HAMILTON, P., S. MCDOWELL, E. WADDELL, D. REDFORD, and D. PABST. 1996. Slope sea currents during the 1990-1991 106-mile site investigations. J. Marine Env. Eng., 2: 203-225.

HEIRTZLER, J. R., P.T. TAYLOR, R. D. BALLARD, and R. L. HOUGHTON. MS 1977. The 1974 Alvin dives on Corner Rise and New England Seamounts. WHOI Rep., WHOI-77-08, $53 \mathrm{p}$.

HEIRTZLER, J. R., P. T. TAYLOR, R. D. BALLARD, and R. L. HOUGHTON. 1977. A visit to the New England Seamounts. Amer. Sci., 65: 466-472.

HOGG, N. G., R. S. PICKART, R. M. HENDRY, and W. J. SMETHIE, JR. 1986. The Northern Recirculation Gyre of the Gulf Stream. Deep-Sea Res., 33(9A): 11391165 .

HOUGHTON, R. L., J. R. HEIRTZLER, R. D. BALLARD, and P. T. TAYLOR. 1977. Submersible observations of the New England Seamounts. Naturwissenschaften, 64: $348-355$.

JENSEN, A. and R. FREDERIKSEN. 1992. The fauna associated with the bank-forming deepwater coral Lophelia pertusa (Scleractinaria) on the Faroe Shelf. Sarsia, 77: $53-69$.

KENSLEY, B. 2003. Redescription and distribution of two species of Syscenus (Crustacea, Isopoda) in the North Atlantic. Sarsia, $\mathbf{8 8}$ (in press).

KOSLOW, J. A. 1997. Seamounts and the ecology of deepsea fisheries. Amer. Sci., 85: 168-176.

KOSLOW, J. A. and K. GOWLETT-HOLMES. MS 1998. The seamount fauna off southern Tasmania: benthic communities, their conservation and impacts of trawling. Final report to Environment Australia and the Fisheries Research and Development Corporation. CSIRO, Hobart, Tasmania (Australia) $104 \mathrm{p}$.

KOSLOW, J. A., G. W. BOEHLERT, J. D. M. GORDON, R. L. HAEDRICH, P. LORANCE, and N. PARIN. 2000. Continental slope and deep-sea fisheries: implications for a fragile ecosystem. ICES J. Mar. Sci., 57: 548-557.

MOORE, J. A. and P. M. MACE. 1999. Challenges and prospects for deep-sea finfish fisheries. Fisheries, 24(7): 22-23.

MOORE, J. A., K. E. HARTEL, J. E. CRADDOCK, and J. K. GALBRAITH. 2003. An annotated checklist of deepwater fishes from off New England, with 110 range extensions and 81 new records off New England. Northeast Nat., 10(2): 159-248.

MORTENSEN, P. B., M. HOVLAND, T. BRATTEGARD, 
and R. FARESTVEIT. 1995. Deep water bioherms of the scleractinian coral Lophelia pertusa (L.) at $64^{\circ} \mathrm{N}$ on the Norwegian shelf: structure and associated megafauna. Sarsia, 80: 145-158.

POHLE, G., T. J. KENCHINGTON, and R. G. HALLIDAY. 1992. Potentially exploitable deepwater resources off Atlantic Canada. Can. Tech. Rep. Fish. Aquat. Sci., 1843: $1-79$.

PRATT, R. M. and S. L. THOMPSON. MS 1962. Report on Atlantis cruises \#280-281, June-July 1962. WHOI Rep., WHOI-62-40, $48 \mathrm{p}$.

PROBERT, P. K., D. G. MCKNIGHT, and S. L. GROVE. 1997. Benthic invertebrate bycatch from a deep-water trawl fishery, Chatham Rise, New Zealand. Aquat. Conserv.: Mar. Freshw. Ecosyst., 7: 27-40.

ROGERS, A. D. 1994. The biology of seamounts. Adv. Mar. Biol., 30: 305-350.

ROGERS, A. D. 1999. The biology of Lophelia pertusa (Linnaeus, 1758) and other deep-water reef-forming corals and impacts from human activity. Int. Rev. Hydrobiol., 84(4): 315-406.

SLEEP, N. H. 1990. Monteregian hotspot track: a long-lived mantle plume. J. Geophys. Res., 95(B13): 21,983-
$21,990$.

UCHUPI, E, J. D. PHILLIPS, and K. E. PRADA. 1970. Origin and structure of the New England Chain. Deep-Sea Res., 17: 483-494.

VASTANO, A. C. and B. A. WARREN. 1976. Perturbations of the Gulf Stream by Atlantis II seamount. Deep-Sea Res., 23: 681-694.

VECCHIONE, M. 2000. Cephalopods of the continental slope east of the United States. in: G. Sedberry (ed.) Islands in the Stream. Oceanography and Fisheries of the Charleston Bump. Amer. Fish. Soc. Sym., 25: 153-160.

VECCHIONE, M. and G. POHLE. 2002. Midwater cephalopods in the western North Atlantic Ocean of Nova Scotia. Bull. Mar. Sci., 71: 883-892.

VINNICHENKO, V. I. 1997. Russian investigations and deep water fishery on the Corner Rising Seamount in Subarea 6. NAFO Sci. Council Studies., 30: 41-49.

WILSON, R. R., JR. and R. S. KAUFMAN. 1987. Seamount biota and biogeography. In: Seamounts, islands, and atolls. B. H. Keating, P. Fryer, R. Batiza, and G. W. Boehlert (eds.). Geophys. Monogr., No. 43, p. 355-377.

ZEIGLER, J. M. MS 1955. Seamounts near the eastern coast of North America. WHOI Rep., WHOI-55-17, 36 p. 